\title{
ANALISIS KESIAPAN PEMILIHAN UMUM KEPALA DAERAH KABUPATEN TUBAN DI TENGAH PANDEMI COVID-19
}

\author{
Yessika Nurmalasari ${ }^{*}$, Agus Machfud Fauzi ${ }^{2}$
}

Program Studi Sosiologi, Fakultas Ilmu Sosial Dan Hukum, Universitas Negeri

Surabaya, Surabaya, Jawa Timur, Indonesia

*Email : yessika.nurmalasari@gmail.com

\begin{abstract}
Elections are activities that aim to elect the leader of a region. Regional head elections held in 2020 are slightly different elections compared to elections in previous years. This difference is related to the Covid-19 pandemic that plagues the world, including Indonesia. The 2020 election sparked pros and cons in the community. Using digital literacy methods with a qualitative approach, this article examines the readiness of Tuban Regency in the face of the 2020 elections. Based on the results obtained, Tuban Regency held elections in 2020 with various preparations that meet health protocols. Like when conducting voter registration, the recorded officer uses a complete self-supporting tool to prevent the transmission of the Covid-19 virus.
\end{abstract}

Keywords : 2020 election, Covid-19

\begin{abstract}
Abstrak
Pemilihan umum merupakan kegiatan dimana bertujuan untuk memilih pemimpin suatu wilayah. Pemilihan umum kepala daerah yang diselenggarakan di tahun 2020 merupakan pemilihan umum yang sedikit berbeda dibandingkan dengan pemilihan umum di tahun-tahun sebelumnya. Perbedaan ini terkait dengan adanya pandemi Covid-19 yang mewabah di seluruh dunia, termasuk Indonesia. Pilkada 2020 yang memicu adanya pro dan kontra dalam masyarakat. Dengan menggunakan metode literasi digital dengan pendekatan kualiatatif, artikel ini mengkaji tentang kesiapan Kabupaten Tuban dalam menghadapi pilkada 2020. Berdasarkan hasil yang didapat, Kabupaten Tuban mengadakan pilkada 2020 dengan berbagai persiapan yang memenuhi protocol kesehatan. Seperti saat melakukan pendataan pemilih, petugas yang mendata menggunakan alat pelingdung diri yang lengkap guna mencegah penularan virus Covid-19.
\end{abstract}

Kata kunci : Pilkada 2020, Covid-19 


\section{PENDAHULUAN}

Covid-19 merupakan salah satu virus yang muncul pada akhir tahun 2019 di Wuhan, China. Virus tersebut merupakan salah satu virus yang berbahaya dan sudah mengakibatkan ribuan korban meninggal. Covid-19 juga telah menyebar ke berbagai penjuru dunia termasuk Indonesia. Indonesia sendiri merupakan negara dengan jumlah kasus Covid-19 tertinggi. Jumlah pengidap Covid-19 di Indonesia sendiri mencapai 415.000 kasus. Yang mana artinya penyebaran virus bisa dibilang sangat mudah.

Adanya Covid-19 ini mengakibatkan banyak kegiatan menjadi terbengkalai. Protokol kesehatan harus selalu dipatuhi ketika beraktivitas di luar ruangan dan ketika berkumpul dengan banyak orang. Masyarakat harus selalu memakai masker, membawa handsanitizer, dan dilarang untuk bersentuhan secara fisik dengan orang lain.

Banyak kegiatan yang tertunda dan dibatalkan karena adanya virus Covid-19. Namun, dibalik banyaknya agenda-agenda yang dibatalkan, ada satu agenda besar yang nyatanya masih tetap diberlangsungkan di Indonesia, yaitu dilaksanakannya Pemilihan Umum Kepala Daerah. Terdapat berbagai pertanyaan dalam masyarakat mengenai megapa pemilu tetap diberlangsungkan padahal Covid-19 masih belum teratasi? Pertanyaan tersebut tentunya menimbulkan beragam spekulasi pada masyarakat.

Pelaksanaan pemilu di tengah pandemic Covid-19 memunculkan tanggapan prodankontra dalam masyarakat. Seperti yang dikatakan oleh Ketua Konstitusi dan Demokrasi Inisiatif Veri Junaedi dalam Kompas, pelaksanaan pemilu dirasa tidak efektif apabila tetap dilaksanakan pada Desember 2020. Menurutnya, hal ini lantaran tidak adanya anggaran yang cukup untuk mejamin kesehatan dan keselamatan penyelenggara, panitia, serta pemilih di tangah pandemic Covid-19. Dengan tidak adanya penundaan pemilu tersebut, dikhawatirkan virus Covid-19 akan menular dengan massif di tengah masyarakat.

Selain itu, menurut penuturan Ego Primahyoga, peneliti Indonesia Corruption Watch (ICW) dalam katadata, apabila pemilu tetap dilaksanakan pada Desember 2020, akan terjadi banyak kecurangan. Praktik-praktik 
politik udang akan marak terjadi di era pandemi seperti saat ini. Hal ini merujuk pada banyaknya masyarakat yang kesulitan untuk memenuhi kebutuhan hidup di tengah pandemi. Selain khawatir akan terjadi banyaknya kecurangan, Ego juga khawatir jika jumlah pemilih akan mengalami penurunan. Hal ini terkait dengan besarnya penularan virus Covid-19 apabila masyarakat datang untuk memilih.

Bertolak belakang dengan yang dipaparkan oleh Veri Juanedi dan Ego Primahyoga, Menteri Dalam Negeri Tito Karnavian justru menilai bahwa tidak ada lagi alasan untuk menunda pemilu 2020. Menurut penuturannya, tidak aka nada jaminan Covid-19 akan berakhir pada 2021. Pelaksanaan pemilu pada Desember 2020 ini harus tetap dilakukan karena pihaknya hanya menggeser jadwal pemilu, yang semula disepakati pada September 2020 menjadi Desember 2020.

Selain penuturan tentang tetap dilaksanakannya pemilu pada 2020 yang dipaparkan oleh Tito Karnavian, juru bicara Presiden Jokowi, Fadjroel Rachman juga mengatakan bahwa Indonesia bisa melaksanakan pemilu pada 2020. Beliau mengatakan bahwa negara-negara selain Indonesia juga bisa melaksanakan pemilu di tengah pandemi Covid-19. Hal inilah yang membuat Indonesia harus mencontoh negara-ngara seperi Singapura, Korea Selatan dan negara lain yang berhasil melaksanakan pemilu di tengah pandemi. Beliau juga mengatakan bahwa pelaksanaan pilakada 2020 harus tetap memperhatikan protokol kesehatan demi mencegah penularan virus Covid19.

Meskipun gugus tugas penanganan Covid telah dikerahkan dan harus tetap menjaga protokol kesehatan, namun masih terdapat kekhawatiran yang dirasakan oleh masyarakat dalam mengikuti pemilu. Selain kekhawatiran akan terjadinya penularan, terdapat satu isu terkait isu anggaran dan permasalahan teknis. Anggaran yang digunakan untuk pemilu 2020 sejumlah 4,7 M membuat pemilu tahun ini menjadi pemilu yang mahal ${ }^{1}$. Hal ini

${ }^{1}$ Sri Nuryanti, Et.al. 2020. Polemik Penyelenggaraan Pilkada Serentak Di Masa Pandemi Covid-19. Jakarta:Pusat Penelitian Politik, Lembaga Ilmu Pengetahuan Indonesia (P2P-LIPI). Halaman 3. 
dikarenakan adanya pengadaan Alat Pelindung Diri (APD) dan pengadaan alat bantu pemilihan di TPS yang harus memenuhi standar aman Covid-19. Anggaran yang seharusnya terdistribusi pada bulan Juni 2020, nyatanya hingga Juli 2020 belum semua daerah mendapatkan anggaran. Apabila anggaran belum terdistribusi dengan merata ke setiap daerah, dikhawatirkan akan mengganggu proses pelaksanaan pilkada 2020. Anggaran dana juga harus dicairkan tepat sasaran agar nantinya tidak sisalahgunakan oleh pihak lain.

\section{METODE}

Penelitian ini menggunakan metode kualitatif dengan menggunakan teknik studi pustaka. Studi pustaka ini merupakan teknik yang digunakan dalam penelitian kaulitatif dengan cara mengambil sumber data dari artikel, berita, jurnal dan sumber bacaan yang terpercaya. Peneliti menelaah sumbersumber dari artikel, berita, jurnal yang kemudian akan diolah dan bisa digunakan untuk menghasilkan pokok bahasan artikel. Alasan pengambilan data menggunakan studi pustaa adalah karena saat ini merupakan masa pandemic. Yang mana kita dianjurkan untuk tetap menjaga jarak dengan orang lain. Alasan kedua adalah saat ini sudah banyak media dari internet yang memberitakan dan menginformasikan mengenai pilkada 2020, yang tentunya isi dari informasi tersebut bisa digunakan peneliti dalam mengambil data. Dengan menggunakan teknik studi pustaka, peneliti akan mencari sumber-sumber dengan cara browsing dari internet, membaca berbagai literature, baik dari artikel, jurnal maupun berita yang relevan dengan pokok bahasan dalam artikel yang disusun ini.

\section{PEMBAHASAN}

Menurut Joko J. Prihantoro dalam Hani, Pilkada atau pemilihan kepala daerah merupakan rekrutmen politik yang mana didalamnya ada penyeleksian yang dilakukan rakyat terhadap tokoh-tokoh yang mencalonkan diri sebagai kepala daerah, baik itu Gubernur dan wakil gubernur, Walikota dan wakil walikota serta Bupati dan wakil bupati. Dalam 
kehidupan setiap daerah, keberadaan kepala daerah menjadi bagian penting dan tak terpisahkan. Hal ini karena kepala daerah merupakan tokoh yang dipilih masyarakat dan dianggap mampu untuk memajukan kesejahteraan daerah dan mayarakat didalamnya.

Pemilihan kepala daerah yang diselenggarakan di Indonesia merupakan pilkada langsung. Pilkada langsung merupakan pilkada yang mana para calon kandidat dipilih langsung oleh rakyat. Pemilihan umum kepala daerah yang dilakukan secara langsung ini merupakan kebutuhan yang dilakukan guna mengoreksi apakah ada penyimpangan yang dilakukan oleh para elit ditingkat lokal dalam penerapan otonomi daerah ${ }^{2}$.

Pemilihan umum kepala daerah yang dilakukan secara langsung adalah bentuk nyata dari pembentukan demokratisasi di daerah ${ }^{3}$. Pemilihan umum yang berlangsung dilaksanakan secara luber jurdil yakni langsung, umum, bebas, rahasia juur dan adil. Pemilu secara luber jurdil dilakukan guna mendapatkan kepercayaan masyarakat mengenai calon kepala daerah yang dipilih. Hal ini karena dengan menerapkan pemilu yang luber jurdil, setiap pemillih berhak memilih siapapun tanpa ada paksaan dari pihak lain.

Dalam pelaksanaan pemilu, terdapat banyak tahapan didamnya. Salah satunya adalah pelaksanaan kampanya yang biasa dilakukan oleh masingmasing paslon. Kampanye yang biasa dilakukan sering diselenggarakan di lapangan yang mengundang banyak massa. Pengadaan kampanye seperti itu dilakuan guna menarik perhatian masyarakat agar nantinya masyarakat memilih paslon tersebut. Namun hal ini berbeda dengan pilkada yang diselenggarakan pada tahun 2020.

Pilkada 2020 merupakan pilkada yang diwarnai banyak pro dan kontra. Hal ini karena pilkada 2020 diadakan di tengah-tengah pandemi Covid-19. Banyak masyarakat yang setuju mengenai pelaksanaan pemilu dan tak sedikit pula yang tidak setuju mengenai dilaksanakannya pemilu di tahun 2020.

${ }^{2}$ Hani Adhani.2009. Proses penyelesaian sengketa pilkada pasca perubahan kedua undang-undang nomor 32 tahun 2004 tentang pemerintahan daerah. Tesis diterbitkan. Jakarta:Universitas Indonesia. Halaman 17.

${ }^{3}$ Ibid. 
Di samping pro dan kontra yang terjadi di masyarakat mengenai keberangsungan pemilu kepala daerah 2020, pemerintah teteap setuju dan telah menetapkan bahwa pemilu kepala daerah tetap dilaksanakan pada tahun 2020, tepatnya bulan Desember mendatang. Ada sekitar 270 daerah yang nantinya akan melaksanakan pemilu serentak di tahun 2020. Rincian untuk daerah yang megikuti pilkada 2020 adalah sebanyak 9 provinsi yang melaksanakan pemilihan gubernur, 224 kabupaten yang melaksanakan pemilihan bupati dan 9 kota madya yang akan melaksanakan pemilihan walikota4. Salah satu daerah yang melaksanakan pilkada 2020 adalah Kabupaten Tuban.

Sebelum penetapan paslon bupati dan wakil bupati KPU Kabupaten Tuban melakukan persiapan guna menghadapi pemilu pada Desember mendatang. Salah satu persiapan yang dilakukan KPU adalah dengan mendata para calon pemilih. Pendataan calon pemilih ini dilakukan sebagai proses pemutakhiran daftar pemilih tetap. Pendataan yang dilakukan pada kurun waktu sekitar 1 bulan yang diselenggarakan pada 15 Juli - 13 Agustus 2020 dilakukan oleh petugas PPDP. Petugas Pemutakhiran Data Pemilih (PPDP) mendata para calon pemilih dengan mendatangi tiap-tiap rumah. Pendataan yang dilakukan saat ini terlihat berbeda dari pemilu-pemiu sebelumnya. Pasalnya, ditengah pandemi Covid-19 ini, PPDP diharuskan menggunakan alat pelindung diri atau APD untuk menghindari penularan virus Covid-19. Seperti yang diungkapkan oleh Nisa, anggota PPDP Kecamatan Senori, Kabupaten Tuban, bahwa ia bersyukur karena masyarakat telah paham mengenai kondisi saat ini. Meskipun banyak msayarakat yang terkejut dan kaget melihat Nisa memakai APD, namun Nisa tetap bisa berkomunikasi dengan baik saat melakukan pendataan.

Setelah seluruh pendataan calon pemilih tetap dilakukan, tahap selanjutnya adalah pendaftaran calon kepala daerah. ke Komisi Pemilihan

\footnotetext{
4 Lihat detik.com. 2019. Ini 270 Daerah Yang Gelar Pilkada Serentak 2020. https://news.detik.com/berita/d-4596501/ini-270-daerah-yang-gelar-pilkada-serentak-2020 Diakses pada 15 Novmber 2020.
} 
Umum. Pendaftaran tersebut dimulai pada 4 September hingga 6 September 2020.

Kabupaten Tuban merupakan kabupaten yang mengususng 3 pasangan calon bupati dan wakil bupati. Pasangan pertama adalah pasangan Khozanah Hidayati-Muhammad Anwar, paslon nomor dua adalah Aditya Halindra Faridzki-Riyadi serta yang terakhir adalah paslon nomor urut tiga Setiajit-Armaya Mangkunegara.

Dalam menghadapi pilkada 2020, para paslon mempersiapkan berbagai hal untuk menarik simpati masyarakat. Mulai dari diadakannya kampanye, pemasangan banner di tepi-tepi jalan, hingga mempersiapkan visi misi yang nantinya menjadi sumbangan terebesar tiap-tiap paslon untuk menarik simpatisan masyarakat. Dalam hal penyampaian visi-misi dari masing-masing paslon, disampaikan melalui debat pilbup.

Berbeda dengan pilkada tahun-tahun sebelumnya, yang mana kampanye biasa dilakukan dengan mengundang banyak massa untuk berkumpul di lapangan, pilkada tahun 2020 merupakan pilkada yang berbeda. Pada tahun 2020, kampanya yang dilakuan dengan mengundang banyak massa dilarang pelaksanaanya. Hal ini tak lain karena adanya pandemi Covid-19.

Kampanye merupakan suatu kegiatan yang dilakukan oleh sejumlah kelompok tertentu guna mendapatkan simpati masyarakat. Menurut Rogers dan Storey (1987) dalam Umaimah, mendefinisikan bahwa kampanye merupakan suatu rangkaian tindakan komunikasi yang dilakukan secara terencana dan bertujuan untuk menciptakan efek tertentu pada khalayak dan pelaksanaannya secara berkelanjutan pada kurun waktu tertentu. Sedangkan menurut Dan Nimo dalam Umaimah, kampanye merupakan suatu upaya yang dilakukan guna mempropagandakan pemberi suara yang potensial. Berdasarkan pengertian tersebut, bisa disimpulkan bahwa kampanye merupakan komunikasi politk yang dilakukan guna memperoleh dukungan masyarakat.

Meskipun kampanye yang mengundang banyak massa dilarang, namun kampanye yang dilakukan dengan memasang alat peraga kampanye 
menjadi alternative bagi para paslon agar lebih dikenal oleh masyarakat. Pemasangan alat peraga kampanye dipasang di ruas-ruas jalan dengan menggunakan banner sebagai alat peraga. Namun meskipun dengan menggunakan banner, masih terdapat pelanggaran yang dilakukan oleh paslon kepala daerah. Seperti pelanggaran yang dilakukan oleh tim pemenangan pasangan nomor urut tiga, pelanggaran dikarenakan pemasangan banner di Kecamatan Parengan. Pemasangan banner kampanye tersebut dirasa merupakan pelanggaran oleh Pantitia Pengawas Kecamatan Parengan. Ketika Panwascam Parengan, Dewi Ambar, mengkonfirmasi mengenai mengapa APK dilepas karena hal ini merupakan tindak lanjut dari instruksi Bawaslu nomor 066 /K.JI-28/PM.00.02/IX/20205. Instruksi tersebut berisi bahwa saat itu masih belum memasuki masa kampanya, sehingga banner yang terpasang harus dicopot.

Berbeda kegiatan, paslon dengan nomor urut satu, Khozanah Hidayati-Muhammad Anwar melakuan kegiatan pengukuhan tim sukses dengan tetap menerapkan protokol kesehatan. Pengadaan pengukuhan tim sukses paslon nomor urut satu tesebut mengindikasikan bahwa paslon nomor urut satu siap melenggang menuju pilkada. Acara tersebut berlangsung dengan tetap memperhatikan protokol kesehatan, yang man bisa dilihat dari disediakannya fasilitas tanggap covid-19 dan penggunaan masker selama acara berlangsung ${ }^{6}$.

Persiapan pilkada 2020 yang selanjutnya adalah diadakannya debat publik cabup dan cawabup Tuban. Debat merupakan pertentangan dari suatu argumentasi7. Debat dilakukan guna mengetahui berbagai sudut pandang masing-masing pihak terhait terhadap isu tertentu. Alasan digunakannya

5 Muhammad Abdul Wahab. Sempat Dicopot Panwas, Paslon Setia-Negara Kembali Pasanng APK Di Parengan. https://jatimtimes.com/baca/224900/20200929/090300/sempatdicopot-panwas-paslon-setia-negara-kembali-pasang-apk-di-parengan-tuban. Diakses pada 21 November 2020.

${ }^{6}$ M.Wahab. 2020. Patuhi Protokol Kesehatan, Paslon Aman Kukuhkan Tim Sukses. https://jatimtimes.com/baca/223567/20200913/165700/patuhi-protokol-kesehatan-paslon-amankukuhkan-tim-sukses Diakses pada 21 November 2020.

${ }^{7}$ Rachmat nurcahyo. Panduan Debat Bahasa Indonesia. http://staffnew.uny.ac.id. Diakses pada 20 November 2020. Halaman 3. 
debat oleh suatu pihak terkait yakni ingin menciptakan keyakinan orang lain bahwa opini yang disampaikan lebih baik dibandingkan dengan opini orang lain8. Debat dilakukan bukan karena ingin berdiskusi terhadap suatu persoalan, melainkan ingin memperlihatkan kepada khalayak bahwa argumentasi yang dipaparkan adalah yang paling kuat.

Salah satu tujuan diadakannya debat publik cabup dan cawabup adalah untuk memaparkan visi dan misi dari masing-masing paslon ${ }^{9}$. Pemaparan visi dan misi dari masing-masing paslon diharapkan bisa menggaet banyak simpati dari masyarakat, yang mana nantinya akan berpengaruh pada perolehan suara. Pemaparan visi dan misi juga akan memperlihatkan mengenai kesungguhan dari masing-masing paslon dalam memajukan daerah yang akan dipimpinnya.

Selain persiapan dalam mengelar pilkada 2020 yang dilakukan masing-masing paslon, pihak KPU Tuban juga turut melakukan berbagai persiapan. Salah satunya adalah dengan mengadakan sosialisasi di berbagai daerah di Tuban. Menurut Effendy (1999) dalam Dian, sosialisasi merupakan penyediaaan berbagai sumber pengetahuan yang mana akan menggiring individu untuk bersikap dan bertindak sebagai anggota masyarakat yang sadar akan fungsi sosialnya, sehingga individu bisa turut aktif dalam masyatakat. Pengertian lain menurut KBBI adalah, sosialisasi merupakan proses belajar seorang anggota masyarakat agar bisa meghayati kebudayaan masyarakat dan lingkkungannya ${ }^{10}$. Berdasarkan pegertian-pengertian tersebut, bisa diartikan bahwa sosialisasi merupakan suatu kegiatan yang dilakukan yang mana didalamnya terdapat proses penyampaian nilai-nilai kepada masyarakat. Sosialisasi yang dilakukan KPU Tuban dilakukan secara menyeluruh, mulai dari sosialisasi untuk pemilih pemula, sosialsiasi bagi para nelayan, sosialsiasi bagi para petani, dan juga sosialisasi bagi

${ }^{8}$ Ibid.

9 Khoirul Huda. 2020. Debat Publik, Paslon Akan Kupas Kesejahteraan Rakyat. http://bloktuban.com/2020/11/05/debat-publik-paslon-akan-kupas-kesejahteraan-rakyat/ Diakses pada 21 November 2020.

${ }^{10}$ Cherlinda Hestiane Cahyani. 2019. Sosialisasi Politik Dan Partisipasi Politik: Peran Kesbagpol Terhadap Partisipasi Politik Pemilih Pemula Di Kota Depok Tahun 2018. Skripsi sarjana diterbitkan. Jakarta:UIN Syarif Hidayatullah Jakarta. Halaman 18. 
masyarakat lain. Sosialisasi yang dilakukan juga memiliki tujuan lain, diantarannya adalah untuk meningkatkan kualitas dalam diri setiap individu dalam berpolitik sesuai dengan aturan yang telah ditetapkan ${ }^{11}$. Tujuan lain adalah agar bisa meningkatkan kualitas kesadaran politik masyarakat menuju peran aktif dan meningkatkan partisispasi terhadap pembangunan politik secara menyeluruh ${ }^{12}$.

Sosialisasi yang dilakan oleh KPU merupakan sosialisasi politik. Menurut Ramlan Surbakti, sosialisasi politik adalah metode penyampaian pesan politik dalam satu kesatuan, yang terbagi menjadi dua, yakni pendidikan politik dan indoktrinasi politik ${ }^{13}$. Sosialisasi politik merupakan bagian dari pendidikan politik. Sosialisasi politik tersebut bertujuan agar masyarakat mampu berpartisipasi dalam hal politik melalui aktivitas politik dan sistem politik yang ada.

Sedangkan berdasarkan penuturan Gabriel A.Almond dan G.Bingham Powell Jr, sosialisasi poitik merupakan suatu proses yang mana budaya politik dibentuk, dipelihara dan diubah ${ }^{14}$. Berdasarkan definisi tersebut, terlihat bahwa sosialisasi politik adalah proses dalam pembentukan budaya politik di masyarakat, yang mana didalamnya terdapat pengenalan nilai-nilai politik ${ }^{15}$. Pelaksanaan sosialisasi politik ialah pengenalan nilai-nilai politik yang sifatnya stabil dan berkesinambungan.

Pendapat lain mengenai sosialisasi politik datang dari Kenneth P.Langton. Kenneth mengatakan bahwa sosialisasi politik merupakan cara masyarakat dalam menstransmisikan budaya dari generasi ke generasi ${ }^{16}$. Hal ini tentu terlihat dari adanya sosialisasi politik dan pendidikan politik yang

${ }^{11}$ Lihat Liputan6.com. Tujuan Sosialisasi Politik, Makna Dan Saran Dalam Kehidupan Kewarganegaraan. https://www.liputan6.com/citizen6/read/3874343/tujuan-sosialisasi-politikmakna-dan-sarana-dalam-kehidupan-kewarganegaraan. Diakses pada 20 November 2020.

${ }^{12}$ Lihat Liputan6.com. Tujuan Sosialisasi Politik, Makna Dan Saran Dalam Kehidupan Kewarganegaraan. https://www.liputan6.com/citizen6/read/3874343/tujuan-sosialisasi-politikmakna-dan-sarana-dalam-kehidupan-kewarganegaraan. Diakses pada 20 November 2020.

${ }^{13}$ Cherlinda Hestiane Cahyani. 2019. Sosialisasi Politik Dan Partisipasi Politik: Peran Kesbagpol Terhadap Partisipasi Politik Pemilih Pemula Di Kota Depok Tahun 2018. Skripsi sarjana diterbitkan. Jakarta:UIN Syarif Hidayatullah Jakarta. Halaman 19.

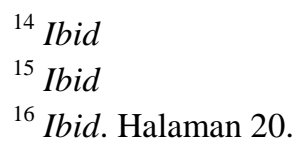


dilakukan KPU kepada para pemilih pemula. KPU mengadakan sosialisasi untuk pemilih pemula bertujuan agar para pemilih pemula bisa mengikuti pemilu dengan antusias dan tidak ada yang golput. Selain itu pihak PPK yatau Panitia Pemilihan Kecamatan, selaku pihak pemberi sosialisasi juga berharap bahwa nantinya pemillih pemula bisa berpartisipasi dalam pemilu cabup dan cawabup dengan tetap menetapkan protokol kesehatan guna menghindari penlaran virus Covid-1917.

Di Indonesia, pemilih pemula biasanya memilih dengan berdaarkan besarnya partai pengusung dan berdasarkan kapasitasnya dalam melakukan kampanye ${ }^{18}$. Hal itu berkaitan dengan masih rendahnya pengetahuan dan informasi yang diperoleh para pemilih pemula. Dengan rendahnya pengetahuan dan informasi yang dimiliki para pemilih pemula, mereka akan cenderung untuk tidak mengikuti pencoblosan atau golput. Agar menghindari banyaknya golput yang dilakukan oleh pemilih pemula tersebut maka diadakanlah sosialisasi politik dan pendidikan politik oleh KPU.

Selain pemberian sosialisasi politik kepada pemilih pemula, KPU Tuban juga menggelar sosialisasi kepada para petani dan nelayan. Pemberian sosialisasi kepada petani bertujuan untuk menjelaskan menegnai tahaptahap pencoblosan. Pihak pemberi sosialisasi KPU yang diwakilkan oleh PPS atau Panitia Pemungutan Suara, Bambang, mengatakan bahwa pemberian sosialisasi bertujuan untuk menyampaiakan tata cara mencoblos kertas suara di TPS. Pemberian sosialisasi tersebut juga menjelaskan mengenai penjelasan suara sah dan tidak sah, serta ketentuan alat yang digunakan untuk mencoblos kertas suara19. Peyampaian sosialisasi tersebut juga dilakukan guna masyarakat mengetahui tata cara pencoblosan di tengah pandemi Covid-19.

${ }^{17}$ Lihat kpud-tubankab.go.id. 2020. Sosialisasi Pemilih Pemula, PPK Kenduruan Sasar Anak SMA. http://kpud-tubankab.go.id/Detail2020 322.htm. Diakses pada 21 November 2020.

${ }^{18}$ Rika Sartika. Sosialisasi Politik Dalam Meningkatkan Kecakapan Partisipatoris Pemula. http://ejournal.upi.edu. Diakses pada 21 November 2020.

${ }^{19}$ Lihat kpud-tubankab.go.id. 2020. Kpud-tubankab.go.id. 2020. Areal persawahan jadi tempat sosisalisasi pilkada oleh PPS Sumurgung. http://kpudtubankab.go.id/Detail2020 320.htm.Diakses pada 21 November 2020.

\section{Borneo Law Review : Vol.5 No.1 Juni 2021}


Pemberian sosialisasi juga dilakukan KPU kepada para nelayan. Pemberian sosialisasi politik dan pendidikan politik yang dilakukan di Desa Palang, Kecamatan Palang, Kabupaten Tuban dilakukan guna mendongrak partisipasi masyarakat dalammenggunakan hak pilih mereka. Komisioner KPU, Zakiyatul Munawaroh menuturkan bahwa sosialisasi politik dan pendidikan politik dilakukan guna memberikan pemahaman kepada masyarakat dan juga tahapan pilkada yang sedang berjalan ${ }^{20}$. Pemberian sosialisasi kepada para nelayan dilakukan untuk memberikan pengetahuan yang mana nantinya bisa disebarluaskan kepada masyarakat luas. Selain itu, berdasarkan penuturan Zakiyah, sosialisasi bertujuan agar masyarakat bisa menjadi masyarakat yang sadar memilih dan masyarakat bisa menjadi pemilih yang cerdas. Pemberian sosialisasi politik dan pendidikan politik kepada masyarakat ini nantinya diharapkan agar masyarakat bisa dengan suka cita menyambut adanya pilkada dan bisa menyebarluasakan pengetahuan yang didapat selama sosialisasi berlangsung.

\section{KESIMPULAN}

Berdasarkan analisis yang telah dilakukan, proses pelaksanaan pemilu di Kabupaten Tuban pada 2020 dipersiapkan dengan baik. Persiapan pilkada 2020 di Kabupaten Tuban dilaksanakan dengan tetap mematuhi protokol kesehatan, mengingat saat ini pilkada dilakukan di tengah pandemi Covid-19. Kesiapan yang dilakukan KPU mulai dari pendataan pemilih dilaukan dengan menerapkan protokol kesehatan. Yang mana petugas yang mendata dilengkapi dengan alat pelindung diri (APD). Selain itu, proses persiapan lain adalah dengan dilakukannya sosialisasi dari KPU kepada masyarakat, seperti pemilih pemula, petani dan nelayan. Pemberian sosialisasi politik dan pendidikan politik dilakukan guna memberikan pengetahuan dan informasi megenai pemilu. Selain itu, pemberian sosialisasi politik dan pendidikan politik dilakukan guna meningkatkan partisispasi masyarakat dalam menggunakan hak pilih mereka dan agar menjadi pemilih yang cerdas.

${ }^{20}$ Lihat kpud-tubankab.go.id. 2020. KPU Tuban Sosialisasikan Pendidikan Pemilih Kepada Nelayan. http://kpud-tubankab.go.id/Detail2020_333.htm Diakses pada 21 November 2020. 


\section{REFERENSI}

Adhani, Hani. 2009. Proses penyelesaian sengketa pilkada pasca perubahan kedua undang-undang nomor 32 tahun 2004 tentang pemerintahan daerah. Tesis diterbitkan. Jakarta:Program Pascasarjana Universitas Indonesia.

Cahyani, Cherlinda. 2019. Sosialisasi Politik Dan Partisipasi Politik: Peran Kesbagpol Terhadap Partisipasi Politik Pemilih Pemula Di Kota Depok Tahun 2018. (Online). Jakarta: Fakultas Ilmu Sosial dan Ilmu Politik, UIN Syarif Hidayatullah Jakarta.

detik.com. 2019. Ini 270 Daerah Yang Gelar Pilkada Serentak 2020. (Online). (https://news.detik.com/berita/d-4596501/ini-270-daerah-yanggelar-pilkada-serentak-2020 Diakses pada 15 Novmber 2020).

Hariyanti, Dini.2020.Pro Kontra Pilkada Di Tengah Optimistis Presiden Terhadap Pandemi.(Online). (https://katadata.co.id/ariemega/berita/5f7954cf6f994/pro-kontrapilkada-di-tengah-optimistis-presiden-terhadap-pandemi. Diakses pada 15 November 2020).

Herdiana, Dian. 2018. Sosialisasi Kebijakan Publk: Pengertian dan Konsep Dasar. (Online). Jurnal ilmiah insan wawasan akademik, 1:3, 13-26.

Huda, Khoirul. 2020. Debat Publik, Paslon Akan Kupas Kesejahteraan Rakyat. (Online).(http://bloktuban.com/2020/11/05/debat-publik-paslonakan-kupas-kesejahteraan-rakyat/ Diakses pada 21 November 2020)

Kpud-tubankab.go.id. 2020. Areal persawahan jadi tempat sosisalisasi pilkada oleh PPS Sumurgung. (Online). (http://kpudtubankab.go.id/Detail2020 320.htm Diakses pada 21 November 2020).

Kpud-tubankab.go.id. 2020. KPU Tuban Sosialisasikan Pendidikan Pemilih Kepada Nelayan. (Online). (http://kpudtubankab.go.id/Detail2020 333.htm Diakses pada 21 November 2020).

Borneo Law Review : Vol.5 No.1 Juni 2021 
Kpud-tubankab.go.id. 2020. Sosialisasi Pemilih Pemula, PPK Kenduruan Sasar Anak SMA. (Online). (http://kpudtubankab.go.id/Detail2020 322.htm Diakses pada 21 November 2020).

Liputan6.com. Tujuan Sosialisasi Politik, Makna Dan Saran Dalam Kehidupan Kewarganegaraan.(Online).

(https://www.liputan6.com/citizen6/read/3874343/tujuansosialisasi-politik-makna-dan-sarana-dalam-kehidupankewarganegaraan.Diakses pada 20 November 2020).

Maharani, Tsarina. 2020. Polemik Pilkada 2020: Di Tengah Pandemi dan Kritik.

(Online).

(https://nasional.kompas.com/read/2020/05/29/08181381/polemi k-pilkada-2020-di-tengah-pandemi-dan-kritik?page=all. Diakses pada 15 November 2020).

Nurcahyo, Rachmat. Panduan Debat Bahasa Indonesia. (Online). (http://staffnew.uny.ac.id Diakses pada 20 November 2020).

Nuryanti, Sri dkk. 2020. Polemik Penyelenggaraan Pilkada Serentak Di Masa Pandemi Covid-19. Jakarta:Pusat Penelitian Politik, Lembaga Ilmu Pengetahuan Indonesia (P2P-LIPI).

Sartika, Rika. Sosialisasi Politik Dalam Meningkatkan Kecakapan Partisipatoris Pemula. (Online). (http://ejournal.upi.edu Diakses pada 21 November 2020)

Wahab, M. 2020. Patuhi Protokol Kesehatan, Paslon Aman Kukuhkan Tim Sukses.(Online).

(https://jatimtimes.com/baca/223567/20200913/165700/patuhiprotokol-kesehatan-paslon-aman-kukuhkan-tim-sukses Diakses pada 21 November 2020).

Wahab, Muhammad. 2020. Sempat Dicopot Panwas, Paslon Setia-Negara Kembali Pasanng APK Di Parengan. (Online). (https://jatimtimes.com/baca/224900/20200929/090300/sempatdicopot-panwas-paslon-setia-negara-kembali-pasang-apk-diparengan-tuban Diakses pada 21 November 2020). 
Wahid, Umaimah. 2016. Komunikasi Politik: Teori, Konsep Dan Aplikasi Pada Era Media Baru, cetakan pertama. Bandung:PT. Remaja Rosdakarya Offset-Bandung. 